\title{
Церква і держава в Україні: між дефіцитарністю впливу та нейтралітетом (соціологічний аспект)
}

\author{
Романенко В.А., Класичний приватний університет
}

Нагальною проблемою як для теоретико-соціологічної рефлексії, так і соціальних практик є проблема відносин між соціальними інститутами церкви і держави в сучасному українському суспільстві. Проблема актуалізується як у зв'язку із невизначеністю прихованих протиріч між ключовими релігійними конфесіями, так і через хибно-нейтральну позицію держави, яка проводить політику невтручання у внутрішні справи церкви, і тим самим фактично потурає розпалюванню міжконфесійної ворожнечі. Основна лінія конфлікту проходить між УПЦ МП, УПЦ КП та греко-католицизмом (уніатством). Багато в чому відмінності між ними стосуються зв'язку відповідних релігійних організацій із лобістськими огрупованнями в спецслужбах, які в той чи інший спосіб продовжують свої «кураторські повноваження» щодо православної церкви. Відносини інших конфесій, які можна розглядати в якості вторинних, стосуються маргінального неопротестантизму, який, проте, вступає у відносини з державою лише у зв'язку із православ'ям і греко-католицизмом.

Інститути релігії в порівнянні з іншими соціальними інститутами більш консервативні та змінюються вкрай повільно. Релігія закріплює сформовані в попередні епохи цінності, норми, соціальні практики, зразки відносин та ін. Трансформація релігійних інститутів відбувається не синхронно зі зміною інших правових, політичних або економічних інститутів. Релігійні інститути більш стійкі, надають стабілізаційний вплив, вносять елемент наступності та забезпечують суспільству його своєрідність. Влада не має можливості надавати пріоритетну підтримку будь-якої з них, в політичному плані вона залежить від електорату не однієї, а сукупності всіх конфесій. Внаслідок цього роль релігійного чинника в суспільному житті країни дещо розмита. Розколи в православ 'ї у своїй соціальній функціональності, обмеженої щодо єдиного Вселенського православ'я, мають деструктивне та дезінтегруюче значення не тільки в церковному, але і в суспільному сенсі.

Ключові слова: патріархат; Православна церква; конфесія; духовенство; церква; контроль; державна релігія

\section{Church and state in Ukraine: between deficits of influence and neutrality (sociological aspect)}

\section{Romanenko V.A., Classical private university}

Author's resume. An urgent problem for both theoretical-sociological reflection and social practices is the problem of the relationship between the social institutions of the church and the state in contemporary Ukrainian society. The problem is actualized both in connection with the uncertainty of the hidden contradictions between the key religious denominations, and through the falsely neutral position of the state pursuing a policy of noninterference in the internal affairs of the church, and, in fact, indulges in inciting inter-confessional hostility. The main line of conflict passes between the UOC-MP and the UOC-KP and Greek-Catholicism (Uniate). In many respects, the differences between them relate to the «connection of the relevant religious organizations with lobbyist renditions in the special services, which to some extent continue their» curatorial powers «in the Orthodox Church. Relations of other faiths that can be considered secondary, concerning marginal neo-Protestantism, which, however, enters into relations with the state only in connection with Orthodoxy and Greek Catholicism.

Institutes of religion in comparison with other social institutions are more conservative and change extremely slowly. Religion consolidates the values, norms, social practices, patterns of relations that have developed in previous epochs. The transformation of religious institutions does not occur synchronously with the change of other legal, political or economic institutions. Religious institutions are more stable, provide stabilization influence, introduce an element of continuity and provide society with its distinctiveness. The authorities are not in a position to give priority support to any of them, politically it depends on the electorate not just one, but the totality of all denominations. As a result, the role of the religious factor in the public life of the country is somewhat blurred, the main thing in the relations between the state and the church is determined though fragile. Splits in Orthodoxy in its social functionality, limited by a single Ecumenical Orthodoxy, have destructive and disintegrating significance, not only in the ecclesiastical, but also in the social sense.

Keywords: patriarchy; Orthodox Church; confession; clergy; church; control; state religion 


\title{
Церковь и государство в Украине: между дефицитарнистю влияния и нейтралитетом (социологический аспект)
}

\author{
Романенко В.А., Классический приватный университет
}

Насущной проблемой как для теоретико-социологической рефлексии, так и социальных практик является проблема отношений между социальными институтами церкви и государства в современном украинском обществе. Проблема актуализируется как в связи с неопределенностью скрытых противоречий между ключевыми религиозными конфессиями, так и через ложно-нейтральную позицию государства, проводящего политику невмешательства во внутренние дела церкви, и тем самым фактически потакающего разжиганию межконфессиональной вражды. Основная линия конфликта проходит между УПЦ МП, УПЦ КП и греко-католицизмом (униатством). Во многом различия между ними касаются связи соответствующих религиозных организаций с лоббистскими групировками в спецслужбах, которые в той или иной степени продолжают свои «кураторские полномочия» по православной церкви. Отношения других конфессий, которые можно рассматривать в качестве вторичных, касающиеся маргинального неопротестантизма, который, однако, вступает в отношения с государством только в связи с православием и греко-католицизмом.

Институты религии по сравнению с другими социальными институтами более консервативны и меняются крайне медленно. Религия закрепляет сложившиеся в предыдущие эпохи ценности, нормы, социальные практики, образцы отношений и др. Трансформация религиозных институтов происходит не синхронно с изменением других правовых, политических или экономических институтов. Религиозные институты более устойчивы, предоставляют стабилизационный влияние, вносят элемент преемственности и обеспечивают обществу его своеобразие. Власть не имеет возможности оказывать приоритетную поддержку какой-либо из них, в политическом плане она зависит от электората не одной, а совокупности всех конфессий. В результате роль религиозного фактора в общественной жизни страны несколько размыта. Расколы в православии в своей социальной функциональности, ограниченной по единому Вселенскому православию, имеют деструктивный и дезинтегрирующие значение не только в церковной, но и в общественной смысле.

Ключевые слова: патріархат; православная церков; конфессия; духовенство; церков; контроль; государственная религия

Цілі статті та постановка завдань.

$\mathrm{M}$ етою статті є побудова описової характеристики відносин української держави із ключовими релігійними конфесіями в Україні. Основними теоретико-методологічними джерелами роботи є ідеї та концептуальні положення, що розробляються в працях зарубіжних вчених, у яких визначені специфіка i методологічні проблеми вивчення релігії, особливо П. Бергера, П. Бурдьє, М. Вебера, Р. Інглхарта, Т. Парсонса, П.Сорокіна, Ю. Хабермаса. Теоретико-методологічна основа статті включає також i результати робіт релігієзнавців, у яких досліджувалося питання впливу релігії на інститути влади та громадянського суспільства - В. I. Гараджа, А. М. Краснікова, В. В. Локосова, Л. М. Мітрохіна, М. А. Мітрохіна, М. П. Мчедлова, Ю. Ю. Синелін, М. О. Шахова, В. Ф. Чеснокова, І. М. Яблокова тощо.

Завданнями статті, у зв'язку із визначеною метою, є: а) визначення засад релігійно-конфесійної політики в Україні; б) побудова характеристики відносин держави із ключовими релігійними конфесіями в контексті цієї релігійної політики.

Наукова проблема, якій присвячено статтю.

Статтю присвячено проблемі дефіцитарності впливу церкви на політику держави при збережен- ні взаємного нейтралітету, що має для суспільства відповідні негативні наслідки.

Виклад основного матеріалу дослідження та обгрунтування отриманих наукових результатів.

Теоретико-методологічною основою даної роботи служать загальнонаукові принципи дослідження соціальної реальності: принципи історизму, всебічності, об'єктивності, конкретності тощо. Також у статті широко використані системний підхід та порівняльний аналіз. Зважаючи на предмет та об'єкт дослідження, що проводиться, в статті використовуються роботи релігієзнавців, філософів, соціологів, істориків, політологів, у яких всебічно висвітлюється дана проблема.

В Україні в широких масштабах відновлюють старі або будують нові синагоги, костьоли, молитовні будинки, православні та уніатські храми, багато $з$ яких насильно відібрали у віруючих в роки комуністичного правління. Природний після 70-річного радянського періоду гонінь на релігію прозелітизм позначився на виборі представниками владної верхівки не тільки різних, часто ворогуючих основних конфесій, а й менш поширених або нетрадиційних для України релігій [9].

УПЦ-КП (Українська Православна Церква - Ки́ївський Патріархат) добре представлена у центрі і на заході України, але має дуже слабкий 
вплив на переважно російськомовні схід і південь. Як і УАПЦ (Українська Автокефальна Православна Церква), вона вважає себе українською автокефальною церквою, але має значні труднощі у своєму визнанні Вселенським Константинопольським чи Московським патріархатами.

УПЦ (МП) (Українська православна церква (Московський патріархат)) посідає перше місце серед церков за чисельністю громад, що більше, ніж УПЦ-КП, УАПЦ і УГКЦ (Українська греко-католицька церква) разом узятих. Хоча це окрема церква, вона знаходиться у підпорядкуванні Російської Православної Церкви (ій надана «широка автономія», тобто вона не є незалежною у повному сенсі), тому не вважається частиною суспільства за національну. Наявність церковного євхаристійного спілкування з іншими Церквами є необхідною умовою для входження у Вселенську Православну Церкву - сукупність Помісних Церков, що перебувають між собою у євхаристійному спілкуванні [7].

Православна еклезіологія не визнає розколи як утворення нових повноправних церков. У вченні про церкви, яке сприймає Вселенське православ'я, стан церковної єдності має сакральний характер, воно ототожнюється з образом св. Трійці. Тому поділу, що доходять до розколів, не передбачається. Розкол - це те, що виходить 3 ряду тотожностей і протилежностей і з еклезіологічної сторони не може називатися церквою. Представники розколів, за влучним висловом св. Кипріяна Карфагенського, занепалі або відпали. Вони поза канонами, затвердженими Вселенськими соборами. У них може бути потенціал тотожного, але оскільки вони виходять за межі підпорядкування будь-якої кіріархальної церкви (так називається материнська церква для новостворюваних від неї автономних або автокефальних церков), їх конфесійна тотожність зникає [11, с. 91-93].

Вчення про єдність церкви, сформоване в першому тисячолітті християнства, стверджувалося в конкретній соціально-історичній реальності. Ідеї цього вчення втілювалися 3 великими труднощами через численні розбіжності. По сьогодні зберігається розбіжність між конфесійним розумінням суспільної ролі православної церковності і їі дійсним положенням у соціумі.

Існує багато причин поділів церкви, при цьому внутрішньоцерковні процеси й зовнішні впливи, що призводять до розколів, при всій конфесійній специфіці православ'я мають в основі соціальну обумовленість, утворену змінами в повсякденному та політико-державному устрої життя суспільства.
Будь-яка держава має модель державно-конфесійних відносин. Відповідно до тієї чи іншої моделі православна церква може існувати в союзі 3 державою, може бути конфронтація між державою і церквою, нарешті, державна влада конфронтує 3 наявною традиційної церквою, може підтримувати та входити в союз з іншою церквою, виставляючи іiі як юрисдикційну альтернативу титульної церкви. С і модель, що передбачає встановлення та зміцнення принципу рівності всіх релігійних об'єднань у державі перед його законом [5, с. 41-45].

Розколи (або за запропонованою термінологією - альтернативні юрисдикційні структури) в православ’ї у своїй соціальній функціональності, обмеженій щодо єдиного Вселенського православ'я, мають деструктивне і дезінтегруюче значення не тільки в церковному, але і в суспільному сенсі. Ці структури, як суб'єкти релігійної ситуації мають статус релігійних меншин. Однак в кінці XX ст. починають 3'являтися альтернативні течії в православ'ї, які об’єднують мільйони прихильників та тисячі громад (як, наприклад, в Україні). Для православ'я це безпрецедентне явище [1].

Такі розколи в православ’ї не є чимось одноманітним. Їх соціально-функціональні характеристики та релігійні практики можуть відрізнятися, зокрема ставленням до канонічних і традиційних принципів. Тут спостерігаються градації: одні називають себе істинно-православними або ревнителями православ'я; інші, навпаки, оновлюють або модернізують релігійні практики та інституційність.

Типологізація поділів і розколів у православ’і показує, що деякі альтернативні структури найбільш близькі за своїми соціально-функціональними характеристиками до церков Вселенського православ’я. Деякі ж далеко відійшли від них, порушуючи канонічні встановлення. Звідси помітно різне ставлення до них із боку Помісних церков: одні піддаються критиці, 3 іншими ж спостерігається тенденція до ведення діалогу[4].

Таке стале поняття, як «розколи в православ'ї» не відображає все різноманіття тих об'єднань, які не підкоряються кіріархальним церквам і не входять у їх юрисдикції. Серед них існують не тільки ті, які колись «відійшли від Матері-Церкви», а й ті, що були створені поза будь-якими Помісними церквами. Тому обгрунтовується застосування й уточнюється зміст більш загального поняття альтернативне православ'я [14, с. 161].

Греко-католицька церква (УГКЦ і Закарпатська митрополія) має 97 \% парафій (понад 3 000) в 
Галичині і Закарпатті, хоча осередок УГКЦ, згідно 3 правилами Ватикану, було перенесено до Києва як столиці України. Головне завдання цієї церкви - проголошення патріархату та розбудова громад у центрі та на сході держави, по-перше, за рахунок українців галицького походження, по-друге православних віруючих, котрі бажають утворення українського патріархату, належно визнаного у всьому світі.

Прихильники надання Українській Греко-католицькій Церкві патріаршого статусу в видах подальшого прозелітизму на Православному Сході не без підстав вважають, що цьому може сприяти ситуація, що склалася в політичному і церковному житті України. Прихильники радикального підходу до уніатського питання розраховують використовувати в своїх інтересах наполегливе прагнення державної влади України створити в країні єдину помісну Церкву. При цьому установа уніатського патріархату дозволила б перехопити в цьому процесі ініціативу Української Православної Церкви, яка, бувши найбільш численною і впливовою конфесією в державі, тим не менш має лише статус митрополії і $є$ для націоналістично налаштованих українських політиків вкрай важким партнером. Українська Православна Церква, по-перше, знаходиться в канонічній єдності з Московським Патріархатом, а по-друге, не бажає об'єднуватися на рівних із відокремленими структурами, незмінно ставлячи умовою церковної єдності покаяння розкольників. Уніатська Церква, навпаки, готова йти на зближення з розкольниками, що вже підтвердила вчиненням разом із ними спільних богослужінь.

У той же час створення уніатського патріархату в Україні може мати ряд негативних наслідків для всієї Католицької Церкви в цілому. Перш за все, для Греко-католицької Церкви в Україні характерна прихильність до націоналістичних настроїв. У разі заснування уніатського патріархату можна побоюватися, що церковно-сепаратистські настрої від розкольників-автокефалістів будуть запозичені греко-католиками, і тоді Ватикан ризикує зіткнутися 3 вимогою якщо не повної самостійності новоствореного патріархату, то найбільшої його автономії.

Українська Греко-Католицька Церква в такому випадку може перетворитися в практично не керовану 3 Риму структуру. Подібний розвиток подій буде ще більш імовірним, якщо відбудеться об'єднання греко-католиків і розкольників-автокефалістів. Посилення автономізації Української Греко-католицької Церкви також здатне загострити та без того досить непрості відносини між гре- ко- і римо-католиками України, які з релігійної площини можуть перейти в сферу національних відносин, особливо 3 урахуванням традиційно пропольської орієнтації римо-католиків України [10, c. 33-34].

Слід також зазначити, що в питанні про заснування уніатського патріархату в Україні можлива поява труднощів канонічного порядку, через те, що до сих пір ще не було історичного прецеденту установи Святим Престолом будь-якого східного уніатського патріархату de novo (хоча II Ватиканський собор відзначав можливість прийняття такого рішення). У складі Католицької Церкви в даний час знаходяться 6 східних уніатської церкви, що мають статус патріархатів. Але всі вони походять від Церков, що вже мали патріарший статус на момент укладення унії з Римом, і Папу Римського не можна визнати канонічним джерелом патріаршої гідності настоятелів цих Церков.

Особливе питання для України - це громади протестантів, до яких відносять як відверто харизматичні церкви, так і велику масу євангельських (баптистських) церков. Щодо кількості таких громад, то вона сягає понад 8000 і в більшості областей держави становить до 50 \% всіх церковних організацій [2, с.211].

Досліджуючи в історичному контексті становлення УПЦ, слід зазначити, що у період загального наростання боротьби за незалежність України глава української метрополії РПЦ Філарет (Михайло Денисенко) зібрав у листопаді 1991 року Помісний собор УПЦ (перебувала ще в складі РПЦ), який звернувся до Московської патріархії 3 проханням про надання канонічної незалежності. Оцінивши це як розкол та піддавши анафемі Філарета, у квітні 1992 року архієрейський собор РПЦ різко відкинув це прохання. У червні того ж року відбувся Всеукраїнський православний собор, на якому було прийнято рішення про вихід зі складу РПЦ та оформленні самостійної УПЦ Київського патріархату.

Разом із тим Російська Православна Церква вжила заходів щодо збереження своєї присутності в Україні. Ще в жовтні 1990 року архієрейський собор РПЦ надав УПЦ право самостійного управління справами, але зі збереженням підлеглості Московському патріархату. В умовах загрози розколу українського православ'я прихильники Москви обрали митрополитом Київським і всієї України Володимира (Віктор Сабадаш) [8].

У той же період відновлення греко-католицьких структур було ініційовано Комітетом захисту УГКЦ, за наполяганням якого Рада у спра- 
вах релігії при Раді міністрів УРСР 30 листопада 1989 року почала реєстрацію громад цієї конфесії.

Переслідування цієї конфесії в радянський період створило таку ситуацію, що до початку 1990-х років більшість iï ієрархів знаходилося за кордоном, де вони отримали підготовку в католицьких вузах США, Австрії, Ватикану та в цих самих країнах просувалися вгору церковної ієрархії. Лише частина з них отримала духовну підготовку в підпільній семінарії на території України, що змусило УГКЦ особливу увагу приділяти духовній освіті свого кліру в місцевих та зарубіжних навчальних закладах.

В умовах відсутності такої домінуючої ролі однієї конфесії РПЦ, яка характерна для Росії, влада України дотримувалася принципу «рівнонаближення» всіх, крім того на відміну від Росії влада України демонструє лояльне ставлення до Папському престолу.

Різко ворожу позицію стосовно Київського патріархату займає УПЦ МП, розглядаючи його як неканонічну та розкольницьку структуру. Константинопольський патріарх не може не враховувати, що при визнанні самостійності українського православ'я в країні неминуче різко загостриться релігійна ситуація - фактично на одній території діятимуть дві «помісні» православні церкви, а це призведе до нового переділу підпорядкованості громад, церковної власності, до жорстокості міжконфесіональної полеміки. У цих умовах не представляється можливим сподіватися на «державність» православ'я та посилення його впливу в суспільстві. Набуттю такого статусу навряд чи будуть сприяти новітні ідеї про самостійне (без згоди Константинополя) проголошення канонічності та «помісності» українського православ'я, які з'явилися у зв'язку з відсутністю позитивного вирішення цієї проблеми [3, с. 190-191].

У зв'язку з військовою агресією Росії проти України посилилась тенденція переходу прихожан УПЦ МП під юрисдикцію УПЦ КП як індивідуально, так навіть і цілими парафіями та в різних регіонах України — на Волині, Львівщині, Рівненщині, Тернопіллі, Київщині, Херсонщині, Буковині, Вінничині. У період з 25 грудня 2014 року по 15 січня 2015 року фонд «Демократичні ініціативи» спільно з соціологічною службою Ukraininan Sociology Service на замовлення Міжнародного центру перспективних досліджень провели соціологічне опитування громадян на території України (за винятком Луганської області та Криму) стосовно змін у релігійних уподобаннях українців. Тенденція до збільшення кількості прихильників
УПЦ Київського патріархату спостерігається 3 2006 року. УПЦ КП розцінюється більшістю респондентів як «церква українського народу». Тим часом майже $20 \%$ опитаних вважають УПЦ Московського патріархату інститутом «країни-агресора, яка здійснює в Україні підривну діяльність». Найбільш нейтрально українці ставляться до греко-католицької церкви.

УПЦ МП налічує 12714 громад, а Київського патріархату - 4 661. Феномен того, що при такому співвідношенні кількості церков у УПЦ КП більше прихильників, вона пояснила тим, що українці розцінюють дане питання не стільки в якості релігійної приналежності, скільки в контексті національної ідентифікації. Слід зазначити, що до Української православної церкви Київського патріархату віднесли себе миряни більшості регіонів. Єдиним регіоном, де явна більшість визнала свою приналежність до УПЦ МП, є Донбас $55 \%$ (в опитуванні був представлений Донецькою областю). На Галичині більшість населення належить до греко-католицької церкви (67\%). Найбільш неоднорідний склад віруючих виявився на південному заході, де 34\% віднесли себе до греко-католицької церкви, 32\% - до Православної церкви МП, а 22\% - до Православної церкви КП. Найбільше атеїстів на Слобожанщині (19\%) і на Донбасі (17\%) [13], [12].

Серед інших конфесій в Україні певне місце за значимістю займають також іудаїзм та іслам.

Хоча в результаті еміграції в останній чверті XX століття кількість євреїв в Україні значно зменшилася, $з$ початку 1990-х років в ній почався процес масового відновлення культових споруд та навчальних закладів іудаїзму. Істотну роботу в релігійній сфері проводять зарубіжні організації, в тому числі шляхом спрямування служителів культу (наприклад, головний рабин України Яків Дов Блайх приїхав з США), надання допомоги в отриманні релігійної освіти, у відродженні культурних традицій тощо. Щорічно кілька тисяч паломників-хасидів відвідують могилу свого «цадика» в місті Умань. Складаючи лише 0,2\% населення країни, єврейська громада більш активна, ніж інші національні мінорітні групи, що значною мірою пов'язано із зовнішнім фактором - наявністю великої діаспори, контактами з закордонним єврейським бізнесом, але не менш важливе значення мають серйозні позиції представників цього народу в українському бізнесі та засобах масової інформації.

Якщо політична роль єврейської громади в Україні більш вагома, ніж частка в населенні, що 
обумовлено іï відкритістю та широкими контактами в суспільстві, то значно більша за чисельністю мусульманська громада, за оцінкою - близько 4\% населення країни або до 2 млн людей, в тому числі близько 250 тис. кримських татар. На загальнонаціональному рівні Духовне управління мусульман України проводить лінію на підтримку стабільності в суспільстві, виступає проти заборонених в інших країнах радикальних угруповань типу «Хізб ут-Тахрір», «Джамаат Ісла-Мійя» та інших $[6$, с. 300$]$.

\section{Висновки.}

Православ'я, виконуючи функції підтримки основного зразка інституалізованих у суспільстві цінностей і встановлення законності нормативного порядку, пропонує суспільству модель релігійної легітимації влади з характерним для неї моноцентризмом та сакралізацією. Сприяючи символічному зміцненню стратифікаційних поділів, Церква надає стабілізаційний вплив на суспільство, створює основу для визнання соціальних порядків.

Розвиток політичних інститутів у сучасному світі призвело до поділу держави та громадянського суспільства, що має першочергове значення для демократії. Держава відмовилася від контролю за моральною, релігійною та культурною сферами. Ключову роль у цьому стало відігравати громадянське суспільство, становлення якого в країнах Заходу простежується з XVIII ст. Спонтанно та добровільно сформувалися асоціації громадян, захищені від втручання держави, взяли на себе не тільки функції регулювання морального й духовного життя, а й контролю над формуванням і діяльністю органів державної влади. Правитель перестав сприйматися як сакральна, незмінна і непідзвітна фігура, яка веде підданих до трансцендентного порятунку. Форми легітимації влади змінилися. Глава демократичної держави обирається на основі раціональних процедур і розуміється як звичайна, регулярно змінювана своїми виборцями людина.

Таким чином, навіть не дивлячись на військову агресію Росії, що вплинуло на кількість прихожан УПЦ (МП), в Україні жодна 3 конфесій не може претендувати на імператив політичної значущості, на статус основної державної релігії. Разом із тим влада не має можливості надавати пріоритетну підтримку будь-якій із них, в політичному плані вона залежить від електорату не однієї, а сукупності всіх конфесій. Внаслідок цього роль релігійного чинника в суспільному житті країни дещо розмита, головне у взаєминах держави та церкви визначається хоча і крихким, але сталим релігійним статус-кво, а не використанням владою (як в Росіiі) чільної конфесії для посилення своїх внутрішніх та зовнішньополітичних позицій.

\section{БІБІЛІОГРАФІЧНІ ПОСИЛАННЯ}

1. Балаклацький М. А. Вплив релігійних медіаповідомлень на цільову аудиторію: результати соціологічного опитування (за матеріалами протестанських 3МІ України) / М. А Балаклацький // Наукові записки Інституту журналістики: науковий збірник. - Київ, 2014. - Т. 57 (жовтень-грудень). - С. 97-100.

2. Бурдье П. Социальное пространство: поля и практики / П. Бурдье. - М.: Институт экспериментальной социологии; СПб.: Алетейя, 2017. - 576 с.

3. Бурдье П. Социология социального пространства / П. Бурдье. - М.: Институт экспериментальной социологии; СПб.: Алетейя, 2016. - 288 с.

4. Влияет ли религиозность на политическую консолидацию общества? // Социологические исследования. - 2006. № 11. - С. 82-89.

5. Вебер М. Хозяйственная этика мировых религий / М. Вебер. - 2017. - 76 с.

6. Гараджа В. И. Социология религии: Учеб. пособие для студентов и аспирантов гуманитарных специальностей. 3-е изд., перераб. и доп. / В. И. Гараджа. - М.: ИНФРА-М, 2005. - 348 с.

7. Иоас Х. Макс Вебер и происхождении прав человека: исследование культурной инновации / Х. Иоас // Журнал социологии и социальной антропологии. - 2011. - № 1 .

8. Лункин Р. Закон о церковном имуществе: от фактической реституции к превращению Церкви в центр гражданского общества / Р. Лункин // Религия и право. - 2011. - № 1. - С. 10-14.

9. Мчедлова М. М.. Государство и религиозные организации: новые сферы и формы взаимодействия / М. М. Мчедлова // Современная модель отношений религиозных организаций и государства: российский и мировой опыт: материалы научно-практической конференции. - М.: Юрист, 2017. - С. 139-149.

10. Норт Д. Насилие и социальные порядки. Концептуальные рамки для интерпретации письменной истории человечества / Д. Норт, Д. Уоллис, Б. Вайнгаст. - М.: Изд. Института Гайдара, 2011. - 480 с.

11. Синелина Ю. Ю. Концепции секуляризации в социологической теории. Теоретические аспекты изучения религиозности населения в социологии религии / Ю. Ю. Синелина. - М.: ОАО РИЦ ИСПИ РАН, 2009. - 120 с.

12. Смусь А. Г. Передумови виникнення релігійного контенту в сучасному українському мас-медійному просторі / А. Г. Смусь // Наукові записки Інституту журналістики: науковий збірник. - Київ, 2014. - Т. 56 (липень-вересень). - С. $219-222$. 13.Християнська країна // Український тиждень. - № 50. - Режим доступу: http://tyzhden.ua/Publication/7398

14. Между натурализмом и религией. Философские статьи / пер. с нем. М. Б. Скуратова. - М.: Весь мир, $2011 .-336$ с. 


\section{REFERENCES}

1. Balaklatskyi, M.A. (2014). Vplyv relihiinykh mediapovidomlen na tsilovu audytoriiu: rezultaty sotsiolohichnoho opytuvannia (za materialamy protestanskykh ZMI Ukrainy) [The Influence of Religious Media Messages on the Target Audience: Results of a Sociological Survey (Based on Protestant Mass Media in Ukraine)]. Naukovi zapysky Instytutu zhurnalistyky: naukovyi zbirnyk - Scientific Notes of the Institute of Journalism: A Scientific Collection. (Vol. 57). Kyiv [in Ukrainian].

2. Burde, P. (2017). Sotsyalnoe prostranstvo: polia y praktyky [Social space: fields and practices]. Moscow: Institut jeksperimental'noj sociologii; Saint Petersburg: Aleteiia [in Russian].

3. Burde, P. (2016). Sotsyolohyia sotsyalnoho prostranstva [Sociology of Social Space]. Moscow: Institut jeksperimental'noj sociologii; Saint Petersburg: Aleteiia

4. Vlijaet li religioznost' na politicheskuju konsolidaciju obshhestva? [Does religiousity affect the political consolidation of society?]. (2006). Sociologicheskie issledovanija, 11, 82-89[in Russian].

5. Veber, M. (2017). Hozjajstvennaja jetika mirovyh religij [Economic ethics of world religions] [in Russian].

6. Garadzha, V.I. (2005). Sociologija religii [Sociology of Religion]. (3-d ed., rev.). Moscow: INFRA-M [in Russian].

7. Ioas, X. (2011). Maks Veber i proishozhdenii prav cheloveka: issledovanie kul'turnoj innovacii [Max Weber and the origin of human rights: a study of cultural innovation]. Zhurnal sociologii i social'noj antropologii, 1 [in Russian].

8. Lunkin, R. (2011). Zakon o cerkovnom imushhestve: ot fakticheskoj restitucii k prevrashheniju Cerkvi v centr grazhdanskogo obshhestva [The law on church property: from actual restitution to the transformation of the Church into a center of civil society]. Religija i pravo, 1, 10-14 [in Russian].

9. Mchedlova, M.M. (2017). Gosudarstvo i religioznye organizacii: novye sfery i formy vzaimodejstvija [State and Religious Organizations: New Spheres and Forms of Interaction]. Sovremennaja model'otnoshenij religioznyh organizacij i gosudarstva: rossijskij i mirovoj opyt - The Modern Model of Relations between Religious Organizations and the State: Russian and World Experience: Proceedings of the Scientific and Practical Conference. (pp. 139-149). Moscow: Jurist [in Russian].

10. Nort, D. (2011). Nasilie i social'nye porjadki. Konceptual'nye ramki dlja interpretacii pis 'mennoj istorii chelovechestva [Violence and social order. A conceptual framework for interpreting the written history of mankind]. Moscow: Izd. Instituta Gajdara [in Russian].

11. Sinelina, Ju.Ju. (2009). Koncepcii sekuljarizacii v sociologicheskoj teorii. Teoreticheskie aspekty izuchenija religioznosti naselenija $v$ sociologii religii [The concept of secularization in sociological theory. Theoretical aspects of studying the religiosity of the population in the sociology of religion]. Moscow: OAO RIC ISPI RAN [in Russian].

12. Smus, A.H. (2014). Peredumovy vynyknennia relihiinoho kontentu v suchasnomu ukrainskomu mas-mediinomu prostori [Prerequisites for the emergence of religious content in the modern Ukrainian mass-media space]. Naukovi zapysky Instytutu zhurnalistyky: naukovyi zbirnyk - Scientific notes of the Institute of Journalism: a scientific collection. (Vol. 56). (pp. 219-222). Kyiv [in Ukrainian].

13. Khrystyianska kraina [The Christian Country]. Ukrainskyi tyzhden, 50. Retrieved from: http://tyzhden.ua/ Publication/7398 [in Ukrainian].

14. Mezhdu naturalizmom i religiej. Filosofskie stat'i [Between naturalism and religion. Philosophical articles]. (2011). M. B. Skuratova (Trans.). Moscow: Ves myr [in Russian].

\section{Романенко Володимир Андрійович}

Аспірант, кафедра соціології, прикладної психології та соціальної роботи

Класичний приватний університет

69000, Запоріжжя, вулиця Жуковського, 70Б

\section{Romanenko Volodymyr}

Postgraduate student, Department of Sociology, Applied Psychology and Social Work

Classical private university

70B, Zhukovsky St., Zaporizhzhya, 69000, Ukraine

Email: rvwork2@gmail.com

Цитування: Романенко В. А. Церква і держава в Україні: між дефіцитарністю впливу та нейтралітетом (соціологічний аспект) / В. А. Романенко // Науково-теоретичний альманах «Грані». - 2018. - Т. 21. - № 5. - С. 6-12.

Citation: Romanenko, V.A. (2018). Tserkva i derzhava v Ukraini: mizh defitsytarnistiu vplyvu ta neitralitetom (sotsiolohichnyi aspekt) [Church and state in Ukraine: between deficits of influence and neutrality (sociological aspect)]. Scientific and theoretical almanac «Grani», 21(5), 6-12. 